Tropical Journal of Pharmaceutical Research July 2017; 16 (7): 1473-1480

ISSN: $1596-5996$ (print); 1596-9827 (electronic)

(C) Pharmacotherapy Group, Faculty of Pharmacy, University of Benin, Benin City, 300001 Nigeria.

All rights reserved.

Available online at http://www.tjpr.org

Original Research Article

http://dx.doi.org/10.4314/tjpr.v16i7.3

\title{
Formulation and characterization of a novel, photo- initiated small intestinal sub-mucosal wound-healing hydrogel
}

\author{
Gongbo Liu', Qingtao Li $^{2}$, Wenping Wang1, Junzi Jiang', Jiangui Liao', \\ Liangpeng $\mathrm{Ge}^{3}$, Chuan $\mathrm{Cao}^{1}$ and Shirong $\mathrm{Li}^{1}$ \\ ${ }^{1}$ Department of Plastic and Aesthetic Surgery, Southwest Hospital, Third Military Medical University, Chongqing, 400038, \\ ${ }^{2}$ School of Medicine, South China University of Technology, Guangzhou, Guangdong Province, 510006, ${ }^{3}$ Chongqing Academy \\ of Animal Sciences, Chongqing, 402460, China
}

*For correspondence: Email: shironglicq@163.com

Sent for review: 27 April 2017

Revised accepted: 28 June 2017

\begin{abstract}
Purpose: To design and characterize a novel 3-D photo-initiated small intestinal sub-mucosal (SIS) hydrogel for use as a scaffold.

Methods: Two concentrations of hydrogel were used: $10 \mathrm{mg} / \mathrm{mL}$ SIS gel (designated as $1 \%$ hydrogel) and $20 \mathrm{mg} / \mathrm{mL}$ SIS gel (designated as $2 \%$ hydrogel). Cross-sections of the hydrogels were examined by scanning electron microscope. In vitro cell culture was carried out on the hydrogels, and cell count was obtained on each hydrogel at different time points. In addition, hematoxylin-eosin (H\&E) staining was used to assess in vivo biodegradability of the gels, as well as tissue regeneration.

Results: The $1 \%$ hydrogel possessed a larger pore size $(143 \pm 22 \mu \mathrm{m})$ than the $2 \%$ hydrogel (113 \pm $17 \mu \mathrm{m})$ and showed significantly higher biodegradation rate $(22.79 \pm 2.47 \%$ of gel left on day 5$)$ than $2 \%$ hydrogel $(35.37 \pm 4.51 \%$ of gel left on day 5$)(p<0.05)$. However, results from cell culture showed that the $2 \%$ hydrogel had better biocompatibility than $1 \%$ hydrogel. In vivo data revealed that the gels supported cell growth (cell count on days 3 and 5 were $48.33 \pm 17.61$ and $105.67 \pm 21.36$, respectively). Conclusion: These results suggest that SIS hydrogels have a high potential for application in tissue regeneration.
\end{abstract}

Keywords: Extracellular matrix, Small intestinal sub-mucosa, Hydrogel, Wound healing

Tropical Journal of Pharmaceutical Research is indexed by Science Citation Index (SciSearch), Scopus, International Pharmaceutical Abstract, Chemical Abstracts, Embase, Index Copernicus, EBSCO, African Index Medicus, JournalSeek, Journal Citation Reports/Science Edition, Directory of Open Access Journals (DOAJ), African Journal Online, Bioline International, Open-J-Gate and Pharmacy Abstracts

\section{INTRODUCTION}

Native extracellular matrix (ECM) is of great importance to wound healing process because it provides intracellular signals and water to surrounding tissues, and plays a crucial role in stem cell differentiation. Native extracellular matrix is a complex structure that embeds and supports cells in mammalian tissues [1]. It provides a suitable environment that promotes cell adhesion and proliferation through regulating mass transport and nutrients [2]. Traditionally, artificial ECMs are two-dimensional matrices used in cell culture to influence cell behavior $[3,4]$. Recent studies have shown that cells cultured on a two-dimensional matrix possess unnatural bioactivities when compared with cells cultured on a three-dimensional matrix [5-7].

Small intestinal sub-mucosa (SIS) was used as a vascular replacement for the first time about forty years ago $[8,9]$. Currently, SIS is widely used in various fields as a natural biodegradable material, especially in tissue engineering $[10,11]$. 
It is frequently used as ECM after decellularization due to its high content of collagens and growth factors, such as collagen type I, hyaluronic acid, and fibroblast growth factor [12]. However, SIS, in its original form is too thin for cell culturing in three dimensions, a feature which limits its use to culturing in two dimensions [13]. The design of a 3-D scaffold from SIS requires riboflavin (RF) as a non-toxic cross-linking agent.

Riboflavin (vitamin B2) is present in plants and in various animals. It enhances the cross-linking of type 1 collagen and significantly improves the quality of human cornea[14,15]. It is an excellent cross-linking agent for collagen since it has good biocompatibility and can produce free radicals after it is photo-activated by visible light [16]. During photo-activation, reactive oxygen species activate collagen molecules, as a result of which they become cross-linked via covalent bonds [17].

In this study, a novel and facile hydrogel for wound healing was designed by mixing SIS solution with riboflavin (RF) and photo-activating the mixture via exposure to visible light.

\section{EXPERIMENTAL}

\section{Materials}

Trypsin, methanol, chloroform, ethylenediaminetetracetic acid EDTA), sodium dodecylsulfate, $\mathrm{HCl}, \mathrm{N}$-hydroxysuccinimide (NHS), 1-ethyl-3-(3dimethylaminopropyl)carbodiimidehydrochloride (EDC) and $\mathrm{NaOH}$ were purchased from Aladdin $\AA$ (China). They did not require further purification. PBS powder and Live-Cell staining kit were products of Invitrogen.

\section{Preparation of SIS film}

Fresh small intestinal submucosa (SIS-1) was obtained by mechanically removing the serosa and muscular is from the small intestine of swine. The SIS- 1 was cleaned with water until the runoff water became clear. It was then immersed in methanol/chloroform (1:1, v:v) solution and stirred in a temperature-controlled shaker for 12 $\mathrm{h}$ at $4{ }^{\circ} \mathrm{C}$. This was followed by rinsing SIS- 1 with water until the organic solvents were removed, yielding SIS-2. SIS-2 was immersed in a mixture of $0.05 \%$ trypsin and $0.05 \%$ EDTA solution at 4 ${ }^{\circ} \mathrm{C}$ for $12 \mathrm{~h}$. This was thoroughly rinsed with saline solution to yield SIS-3. The SIS-3 membrane was then placed in saline solution with $0.5 \%$ sodium dodecyl sulfate while shaking in a temperature-controlled shaker for $4 \mathrm{~h}$ at 4 ${ }^{\circ} \mathrm{C}$. This resulted in the production of SIS-4. SIS4 was further treated with $0.1 \%$ acetic acid in the same temperature-controlled shaker for another $12 \mathrm{~h}$ at $4{ }^{\circ} \mathrm{C}$. It was then thoroughly rinsed with water to remove the remaining solvents. This gave rise to SIS- 5 which was freeze-dried at -80 ${ }^{\circ} \mathrm{C}$ and stored at $4{ }^{\circ} \mathrm{C}$ prior to further studies.

\section{Preparation of SIS powder}

This was done by following the procedure reported by Andrée [13]. The de-cellularized SIS membranes obtained from last procedure were broken into powder by Beater (AUX, HX-PB1018, China) and then placed in $2 \%$ pepsin solution for $12 \mathrm{~h}$ at $4{ }^{\circ} \mathrm{C}$ to disconnect collagens. Sodium chloride (2M) was used to salt out the solution which was then centrifuged at $8000 \mathrm{rpm}$ for 45 min at $4{ }^{\circ} \mathrm{C}$. The SIS sediment was dissolved in $0.5 \%$ glacial acetic acid at $4{ }^{\circ} \mathrm{C}$. Then the solution was put in a dialysis bag (10KD) and dialyzed against water for 5 days. Water was refreshed every $2 \mathrm{~h}$ during this period. After dialysis, the solution in dialysis bag was freezedried for 4 days at $-80^{\circ} \mathrm{C}$. The freeze-dried SIS was ground to powder by using Beater and refrigerated for further analysis.

\section{Preparation of hydrogels and 3D cell culture matrices}

In the first step, $10 \mathrm{mg}$ of SIS powder was added to $1 \mathrm{~mL}$ of $0.01 \mathrm{M} \mathrm{HCl}$ and stirred overnight for complete dissolution. The SIS solution was then neutralized with $0.1 \mathrm{M} \mathrm{NaOH}$. Thereafter, $20 \mu \mathrm{L}$ of $10 \%$ RF was added to the neutralized SIS solution, followed by exposure to visible light for $15 \mathrm{~min}$ to initiate formation of $1 \%$ SIS hydrogel. The preparation of $2 \%$ SIS hydrogel followed the same procedure, except that $20 \mathrm{mg}$ of SIS powder was used instead of $10 \mathrm{mg}$ of SIS powder.

To capture the cells in the 3-D matrix, $10 \mu \mathrm{L}$ of $10^{6} / \mathrm{mL}$ cell suspension was introduced into1mLof sterilized $2 \%$ SIS solution containing $0.2 \%$ RB. This was then photo-initiated for 15 min to form a 3-D cell culture matrix. The matrix was transferred to a cell culture medium for further tests.

\section{Hydrogel morphology}

The hydrogels were analyzed by first freezing a set of each gel in liquid nitrogen so as to suspend its network structure. This was followed by shattering the gels to obtain their internal structures. The shattered hydrogel pieces underwent two days of freezing-drying. The morphology of the dried hydrogels was examined using a JEOL-5900 scanning electron microscope. 


\section{Water absorption test}

The hydrogels were punched into cylindrical shapes of diameter $10 \mathrm{~mm}$ and $5 \mathrm{~mm}$ in height. The punched-out hydrogel samples were weighed and placed in a 24-well plate with PBS buffer $(\mathrm{pH}=7.4)$. After $24 \mathrm{~h}$, the gels were taken out and the excess surface water was dried off. Their weight was recorded and water absorbed (\%) was calculated as in Eq 1.

Remaining weight $(\%)=\frac{W_{s}-W_{p}}{W_{s}} \times 100 \ldots \ldots(1)$

Where $W_{t}$ refers to the weight of the swollen hydrogel and $W_{0}$ is the original weight of the hydrogel. All tests were conducted in triplicate.

\section{Degradation test}

The test procedures used were based on the method of Zhao [18]. The hydrogels were punched out into cylindrical shapes $10 \mathrm{~mm}$ in diameter and $5 \mathrm{~mm}$ in height. These were placed in a PBS solution for $24 \mathrm{~h}$ at $37{ }^{\circ} \mathrm{C}$. After saturation, they were transferred to a buffer solution with $2 \%$ proteinase $\mathrm{K}$, and placed in a temperature-controlled shaker at $37{ }^{\circ} \mathrm{C}$ for 5 days. The gels were taken out of the shaker and weighed daily. The remaining hydrogel (\%) was calculated as in Eq 2.

Remaining weight $(\%)=\frac{w_{t}}{w_{0}} \times 100 \ldots \ldots(2)$

Where $W_{t}$ refers to the weight of remaining hydrogel at the time of weighing, and $W_{0}$ is the original weight of the hydrogel. All tests were done in triplicate.

\section{Determination of content of growth factors in SIS}

ELISA analysis was used to evaluate the contents of growth factors. First, $100 \mathrm{mg}$ of SIS was ground by a tissue homogenizer in $2 \mathrm{~mL}$ of ice-cold PBS for $30 \mathrm{~s}$ and then cooling on ice for $10 \mathrm{~min}$. This was repeated three times. Then, the homogenate was centrifuged to obtain the supernatant, which was used for ELISA analysis based on manufacturer's protocol. The supernatant was removed to ELISA plates and detected by anti-VFGF, anti-bFGF, anti-TNF- $\alpha$ and anti-TFG- $\beta$. This was followed by addition of the enzyme substrates based on growth factors. After $20 \mathrm{~min}$, an acidic solution was added to stop enzyme reaction. An ELISA reader was used to measure the absorbance at $450 \mathrm{~nm}$ wavelength. The amounts of growth factors (VFGF, bFGF, TNF- $\alpha$ and TFG- $\beta$ ) were calculated from a calibration curve supplied by the kit manufacturer.

\section{Cell culture}

Bone marrow stromal cell lines were incubated with cell culture medium containing $10 \%$ FBS, $100 \mathrm{mg} / \mathrm{L}$ streptomycin and $1 \%$ penicillin at 37 ${ }^{\circ} \mathrm{C}$. The medium was refreshed every day.

\section{In vitro tests}

Live/dead staining was performed to assess the biocompatibility and cytotoxicity of the hydrogels based on the protocol from Invitrogen. The hydrogels were punched out into $6 \mathrm{~mm}$-diameter cylindrical shapes, and placed in a 96-well culture plate. The samples were washed thrice with PBS. In each well, $1 \times 10^{4}$ bone marrow stromal cells (BMSCs) were seeded on the sample, and the culture medium was refreshed daily. On day 1 and day 3 of cell culture, the cells on the samples were stained with a solution containing $2 \mathrm{mM}$ calcein $\mathrm{AM}$ and $4 \mathrm{mM}$ ethidium homodimer for $30 \mathrm{~min}$, and rinsed thrice with PBS. Thereafter, Confocal Laser Scanning Microscopy (CLSM, Olympus FV1000, Japan) was used to capture images of the cells and ImageJ software was used to calculate cell counts based on the images.

\section{In vivo tests}

Mice were bred in a pathogen-free (SPF) unit in the Experimental Animal Center of the Third Military Medical University, Chongqing, China. All animal experimental procedures followed were in accordance with the Animal Ethics Committee of the Third Military Medical University, Chongqing, China (no. SW201605132653). All animal tests and culturing were performed with strict adherence to the recommendations from the Guide for the Care and Use of Laboratory Animals of the National Institutes of Health [19]. Thirty 6-to-8-week-old male C57BL/6 mice with weight in the range of $20-25 \mathrm{~g}$, were selected for the study. Animals were held in single cages under standard environmental conditions and given free access to food (standard pellets) and water.

The precursor of the SIS gel was sterilized at high temperature and high pressure. Mice were anaesthetized with $100 \mu \mathrm{L}$ of $1 \%$ sodium pentobarbital by intraperitoneal injection. When an adequate anesthesia level was reached, the animals were restrained on the operation table in a prone position and the hair on their back was shaved. The exposed skin was sterilized with 75 $\%$ alcohol, after which a $1 \mathrm{cmlong}$ inguinal crease 
incision was made using lancet. The prepared SIS precursor was placed subcutaneously on both sides of the back and photo-initiated for 30 min to form a hydrogel. The incisions were sutured with 6-0 stitches and protected against infection with antibiotic ointment. Material was removed on days 3 and 7 , fixed in $4 \%$ formalin solution for $24 \mathrm{~h}$, and embedded in paraffin. Sections $(6 \mu \mathrm{m})$ were de-paraffinized and stained with hematoxylin-eosin (H\&E) to observe the biocompatibility and degradation of the material under an optical microscope.

\section{RESULTS}

\section{Scheme and structure of SIS photo-initiated hydrogel}

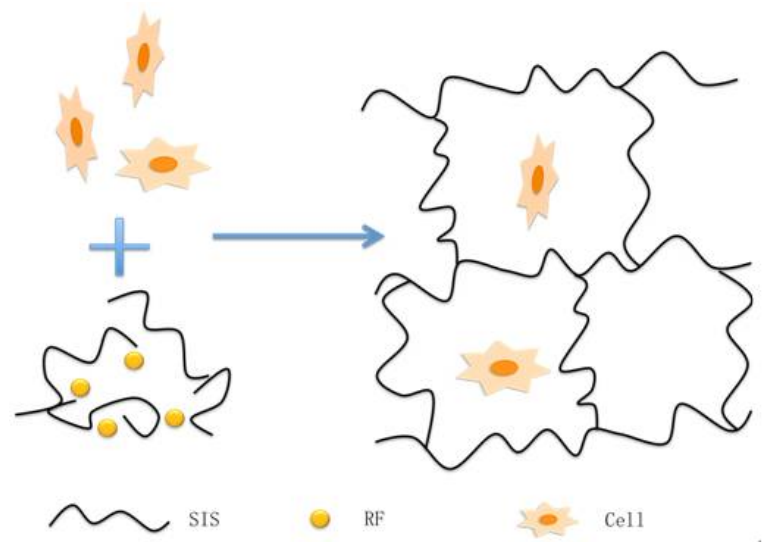

Figure 1: Schematic representation of the formation of SIS 3D cell culture matrix
Different concentrations of sterile SIS were combined with fixed amount of RF solution and then exposed to visible light for $20 \mathrm{~min}$ to produce hydrogels (Figure 1). The 3-D cell culture scaffolds were produced by adding a high concentration of cell suspension to the precursor. This ensured that the cells were captured in the gel.

Figures $2 \mathrm{~A}$ and Figure $2 \mathrm{~B}$ are images of the hydrogels formulated with $1 \%$ and $2 \%$ SIS, respectively. The morphology of the $2 \%$ SIS gel is more solid than that of the $1 \%$ SIS gel. Figures 2C and 2D are SEM images of crosssections of the hydrogels. Both consist of porous structures distributed uniformly throughout the gel matrix. Using ImageJ software, it was observed that the $1 \%$ SIS gel had larger pore size than the $2 \%$ SIS gel (143 $\mu \mathrm{m}$ and $113 \mu \mathrm{m}$, respectively).

\section{Contents of growth factors of SIS}

Results of ELISA analysis of variations in growth factor contents of the four growth factors SIS during the multi-step SIS fabrication process are shown in Figure 3. There were significant decreases $(p<0.05)$ in percentages of VFGF, bFGF, TNF- $\alpha$ and TFG- $\beta$ ) after the first step of the procedure. However, there were no remarkable changes in the percentages of these growth factors during the remaining steps. There were no statistically significant differences in percentages of growth factors between SIS-5 and the SIS gel.
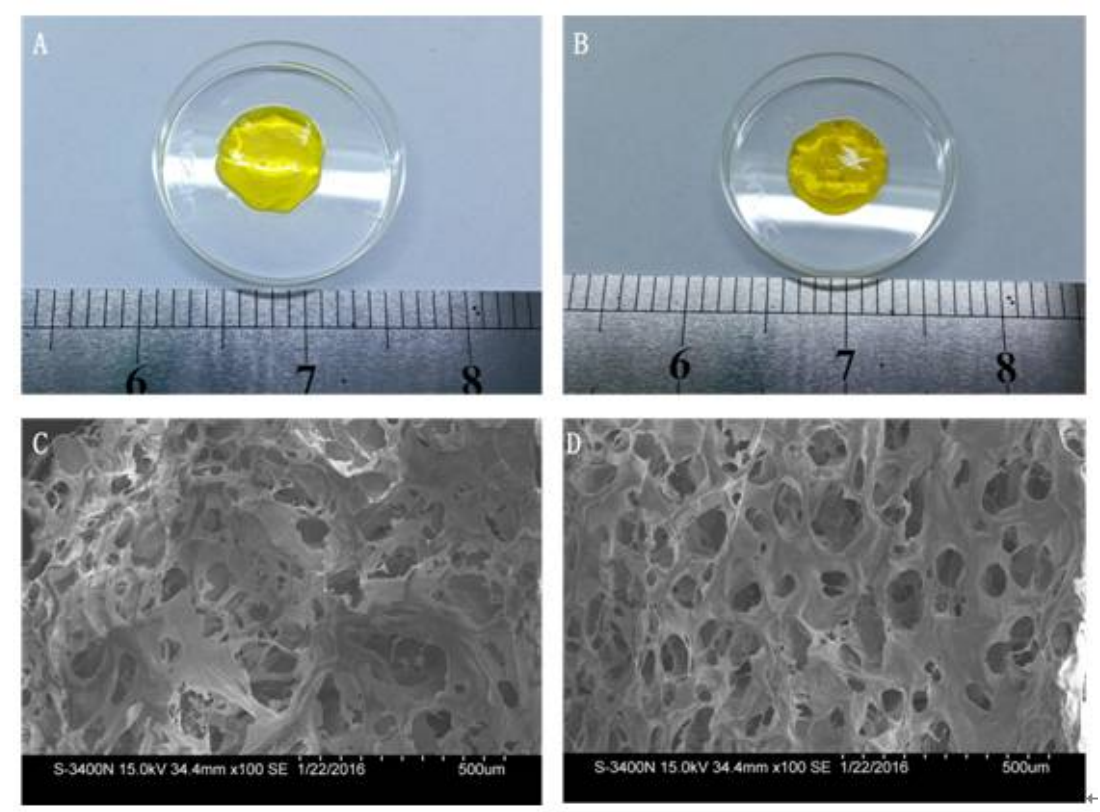

Figure 2: (A) Images of $1 \%$ SIS hydrogel and (B) $2 \%$ SIS hydrogel; (C) SEM images of a cross-section of $1 \%$ SIS hydrogel and (D) a cross-section of $2 \%$ SIS hydrogel 

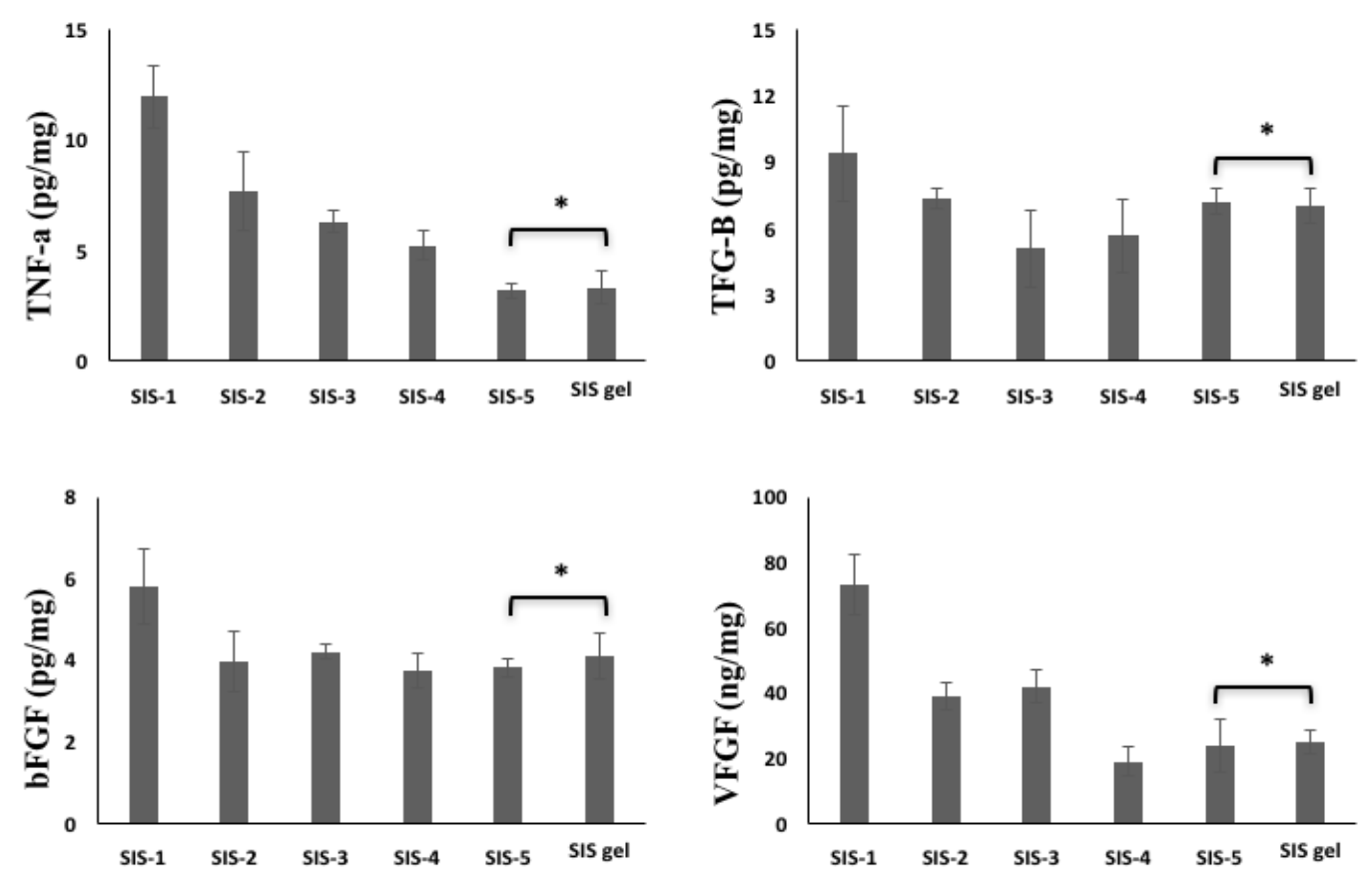

Figure 3: Contents of growth factors in SIS during each step of preparation of SIS powder procedure; ${ }^{*} p>0.05$

\section{Degradation and water absorption of SIS hydrogels}

The degradation tests were performed at $37^{\circ} \mathrm{C}$ while the gels were constantly shaken. The profiles of 1 and $2 \%$ SIS hydrogels are shown in Figure 4. Both gels had weight changes between days 1 and 5 . The $2 \%$ SIS hydrogel group retained $35 \%$ of their original mass, which was $11 \%$ higher than that retained by the $1 \%$ SIS hydrogel group. There were no statistically significant differences infraction of water absorption between the $1 \%$ SIS and the $2 \%$ SIS gels.

\section{In vitro cell viability of SIS hydrogel}

Figure 5 shows fluorescence images of cells cultured in the two gels, and Figure 6 shows the cell counts obtained by analyzing Figure 5 using ImageJ software. On day 1 , the cell count on the $2 \%$ SIS gel was 99 cells, which was by 47 cells higher than that on the $1 \%$ SIS gel (Table 1 ). After 3 days of incubation, the cell counts on both gels were significantly increased, as shown in Figure 5 and 6 . Cell counts increased by 36 on 1 $\%$ SIS gel and by 12 on $2 \%$ SIS gel.
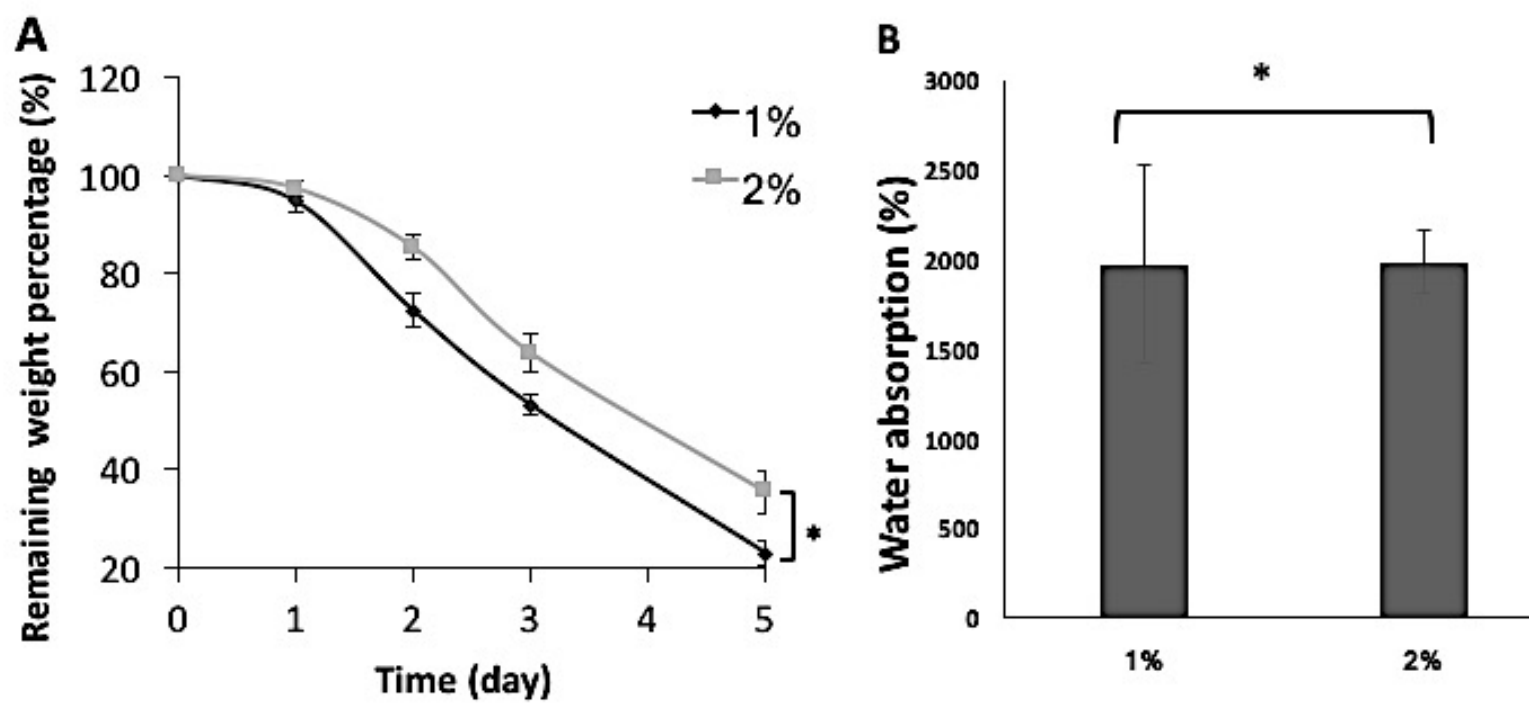

Figure 4: (A) Degradation profiles of the 1 and $2 \%$ SIS hydrogels $\left({ }^{*} p<0.05\right)$; (B) water absorption of 1 and $2 \%$ SIS hydrogels $\left({ }^{*} p>0.05\right)$

Images from H\&E staining 

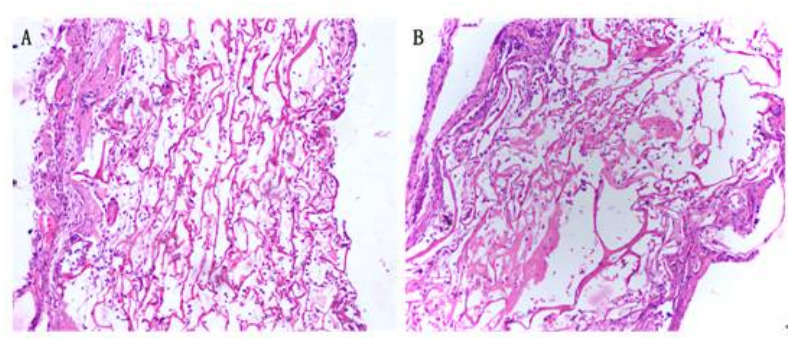

Figure 6: H\&E staining of the $2 \%$ SIS gel on $(A)$ day 3 and $(\mathrm{B})$ day 5 (x100)

Table 1: In vitro cell count on 1 and $2 \%$ SIS hydrogels, on days 1 and 3

\begin{tabular}{|c|c|c|}
\hline Gel type & 1 day & 3 day \\
\hline $\begin{array}{l}1 \% \text { gel } \\
2 \% \text { gel }\end{array}$ & $\begin{aligned} 99.33 & \pm 11.93 \\
146.67 & \pm 8.96\end{aligned}$ & $\begin{array}{l}135.67 \pm 28.36 \\
158 \pm 11.35\end{array}$ \\
\hline
\end{tabular}

Table 2: In vivo cell count in the hydrogels on days 3 and 5

\begin{tabular}{lllr}
\hline Gel type & Time & 3 days & 5 days \\
\hline & & & \\
& & $48.32 \pm$ & 105.67 \\
& 17.62 & \pm 21.36 \\
\hline
\end{tabular}

Figure $6 \mathrm{~A}$ is the H\&E staining image of SIS gel 3 days after implantation. The purple dots represent cells and the red dots represent the gel. The hydrogel structure remained intact with the cells starting to grow in the gel. Five days after implantation, most of the hydrogels had been degraded and had lost their structure. Image $\mathrm{J}$ was used for cell count at six selected squares of the same size from different locations on the gels. The mean numbers of cells are shown in Table 2. On day 5, mean cell number

$1 \%$ SIS gel
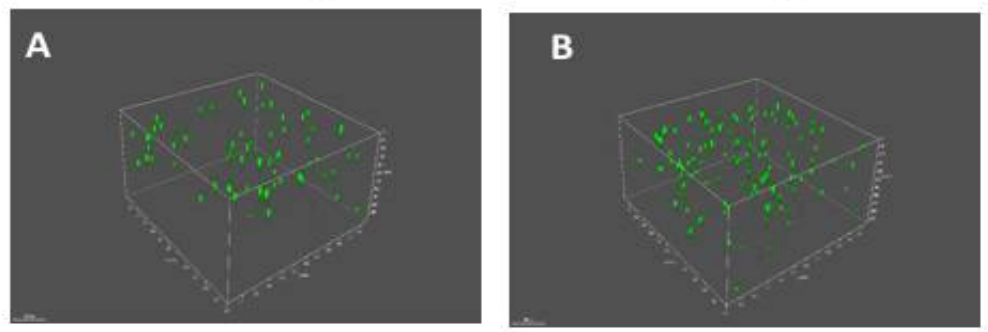

Day 1
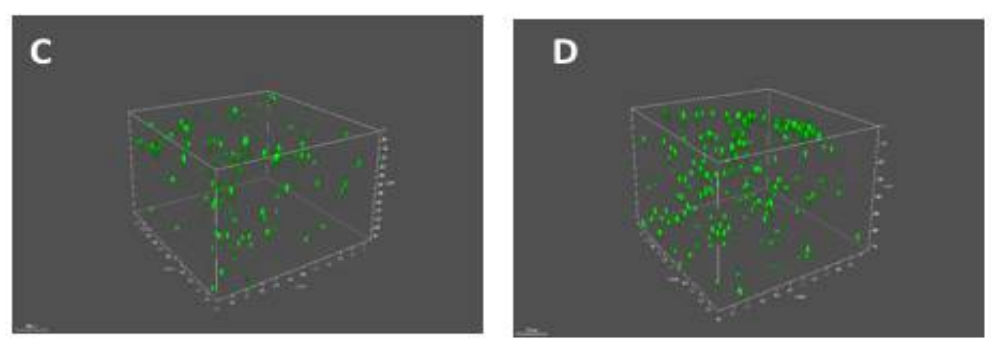
mean number of cells on day 3 .

\section{DISCUSSION} hydrogel might be a potential wound dressing. mentioned above.

Day 3

Figure 5: Florescent images of cells cultured on (A) $1 \%$ SIS gel on day 1, (B) $2 \%$ SIS gel on day 1 , (C) $1 \%$ SIS gel on day 3 , and (D) $2 \%$ SIS gel on day 3

was about 100, which was almost double the

An ideal artificial ECM should provide a suitable and moist environment, possess good biocompatibility for cell adhesion and proliferation, and be biodegradable. Based on SEM images, the $2 \%$ SIS hydrogel possessed a large microporous structure with average pore size of $143 \mu \mathrm{m}$. In Lei Zeng study, it was reported that pore sizes of hydrogels ranging from 80 to $120 \mu \mathrm{m}$, enhance cell proliferation [20]. In this present study, it was found that larger pore size produced better cell adhesion and proliferation, arising from the observation that the cell count from $2 \%$ SIS gel was higher than that from $1 \%$ SIS gel on day 1 and day 3 . The photoinitiated SIS hydrogels displayed good biocompatibility and can support cell migration, proliferation and expansion, indicating the SIS

A moist microenvironment is a necessary requirement for increasing the speed of cell migration. This implies that water absorption of hydrogels is an important quality requirement for artificial ECM. Schunck group discovered a new type of foil that can accelerate cell migration by providing a moist microenvironment. The SIS hydrogel can content up to $2000 \%$ (Fig. 4B), which means the SIS hydrogel is able to keep environment moist and increase cell migration [21]. This result also confirmed the conclusion 
A satisfactory ECM should be biodegradable to avoid second surgery after ECM transplant. The degradation test showed that SIS hydrogels have good biodegradability: After 5 days' degradation, the $2 \%$ SIS hydrogel retained $35 \%$ of gel, while $1 \%$ SIS hydrogel retained $11 \%$ of gel. These results were consistent with those obtained in in vivo tests. The degradation speed is essential for buildup ECM. If degradation took too long, it would have influence on tissue growth and cell function since ECM will build in the pericellular regions. Cell surface receptors would be bonded to many proteins that are used to build ECM and occur a cascade of signals that might be misleading, which could change ECM functions [22].

\section{CONCLUSION}

A photo-initiated SIS hydrogel has been successfully synthesized as an optimal matrix for 3D culturing of cells. The porous structure of the hydrogel provides support for cell adhesion and growth. The SIS hydrogels are biodegradable, which is a key property of ECM, and also displays satisfactory biocompatibility and an ability to support cell proliferation. The findings indicate that these photo-initiated SIS hydrogels are promising biomaterials for tissue engineering.

\section{DECLARATIONS}

\section{Acknowledgement}

None declared.

\section{Conflict of Interest}

No conflict of interest associated with this work.

\section{Contribution of Authors}

The authors declare that this work was done by the authors named in this article and all liabilities pertaining to claims relating to the content of this article will be borne by them.

\section{Open Access}

This is an Open Access article that uses a funding model which does not charge readers or their institutions for access and distributed under the terms of the Creative Commons Attribution License (http://creativecommons.org/licenses/by/ 4.0) and the Budapest Open Access Initiative (http://www.budapestopenaccessinitiative.org/rea d), which permit unrestricted use, distribution, and reproduction in any medium, provided the original work is properly credited.

\section{REFERENCES}

1. Langer R, Vacanti JP. Tissue engineering. Sci 1993; 260(5110): 920-926.

2. Liu YL, Ai KL, Lu LH. Polydopamine and Its Derivative Materials: Synthesis and Promising Applications in Energy, Environmental, and Biomedical Fields. Chem Rev 2014; 114(9): 5057-5115.

3. Chen CS, Mrksich M, Huang S, Whitesides GM, Ingber $D E$. Geometric control of cell life and death. Sci 1997; 276(5317): 1425-1428.

4. Kumar A, Singhvi R. Engineering cell shape and function. Sci 1994; 264(5159) 696-698.

5. Tibbitt MW, Anseth KS. Hydrogels as extracellular matrix mimics for 3D cell culture. Biotechnol Bioengineer 2009; 103(4): 655-663.

6. Petersen OW, Rønnov-Jessen L, Howlett AR, Bissell MJ. Interaction with basement membrane serves to rapidly distinguish growth and differentiation pattern of normal and malignant human breast epithelial cells. Proc Natl Acad Sci 1992; 89(19): 9064-9068.

7. Raeber G, Lutolf M, Hubbell J. Mechanisms of 3-D migration and matrix remodeling of fibroblasts within artificial ECMs. Acta biomaterialia. 2007; 3(5): 615-629.

8. Matsumoto $T$, Holmes RH, Burdick CO, Heisterkamp 3rd $C$, O'Connell Jr TJ. Replacement of large veins with free inverted segments of small bowel: autografts of submucosal membrane in dogs and clinical use. Ann Surg 1966; 164(5): 845.

9. Matsumoto $T$, Holmes RH, Burdick CO, Metzger JF, Heisterkamp CA. A study of inverted intestinal graft in the major veins. Angiology. 1966; 17(11).

10. Badylak SF, Lantz GC, Coffey A, Geddes LA. Small intestinal submucosa as a large diameter vascular graft in the dog. J Surg Res 1989; 47(1): 74-80.

11. Mondalek FG, Lawrence BJ, Kropp BP, Grady BP, Fung $K-M$, Madihally SV, Lin H-K. The incorporation of poly (lactic-co-glycolic) acid nanoparticles into porcine small intestinal submucosa biomaterials. Biomaterials 2008; 29(9): 1159-1166.

12. Hodde J. Naturally occurring scaffolds for soft tissue repair and regeneration. Tissue Eng 2002; 8(2): 295308.

13. Andrée B, Bär A, Haverich A, Hilfiker A. Small intestinal submucosa segments as matrix for tissue engineering: review. Tissue Eng Part B Rev 2013; 19(4): 279-291.

14. Raiskup-Wolf $F$, Hoyer A, Spoerl E, Pillunat LE. Collagen crosslinking with riboflavin and ultraviolet- $A$ light in keratoconus: long-term results. J Cataract Refract Surg 2008; 34(5): 796-801.

15. Wollensak G, Aurich H, Wirbelauer C, Sel S. Significance of the riboflavin film in corneal collagen crosslinking. $J$ Cataract Refract Surg 2010; 36(1): 114-120.

16. Koziol J. Studies On Flavins In Organic Solvents-I. Spectral Characteristics Of Riboflavin, Riboflavin Tetrabutyrate And Lumichrome. Photochem Photobiol 1966; 5(1): 41-54.

Trop J Pharm Res, July 2017; 16(7): 1479 
17. Kato Y, Uchida K, Kawakishi S. Aggregation of collagen exposed to UVA in the presence of riboflavin: a plausible role of tyrosine modification. Photochem Photobiol 1994; 59(3): 343-349.

18. Zhao $C$, Zhuang $X$, He $P$, Xiao $C$, He $C$, Sun J, Chen $X$, Jing $X$. Synthesis of biodegradable thermo-and $\mathrm{pH}$ responsive hydrogels for controlled drug release. Polymer. 2009; 50(18): 4308-4316.

19. Organization WH. Principles of laboratory animal care. WHO Chron 1985; 39: 51-56.

20. Zeng L, Yao Y, Wang DA, Chen X. Effect of microcavitary alginate hydrogel with different pore sizes on chondrocyte culture for cartilage tissue engineering. Mater Sci Eng C Mater Biol Appl. 2014; 34: 168-175.

21. Schunck M, Neumann C, Proksch E. Artificial barrier repair in wounds by semi-occlusive foils reduced wound contraction and enhanced cell migration and reepithelization in mouse skin. $J$ Invest Dermatol 2005; 125(5): 1063-1071.

22. Guilak F, Alexopoulos LG, Upton ML, Youn I, Choi JB, Cao L, Setton LA, Haider MA. The pericellular matrix as a transducer of biomechanical and biochemical signals in articular cartilage. Ann NYAcad Sci 2006; 1068(1): 498-512. 